\section{A.S. Kindo Patengouh}

Aïssata S. Kindo Patengouh teaches General and Comparative Literature, African literature, Oral and Written Expression in the Department of Modern Literature, Abdou Moumouni University, Niamey, Niger. E-mail: akindo2002@yahoo.fr

\title{
Literary production in Niger: The case of the novel
}

\section{Literary production in Niger: The case of the novel}

Literature, like all art, is in part geographically and historically determined. Despite its imaginary nature, literature maintains close ties with its context of emergence. African literature is in part an illustration of determinisms of this type and owes a great deal to colonial trauma. Nevertheless, it also draws on autochthonous myths - both old and new - on the colonial heritage, and on new mentalities generated by decolonisation and other factors. However, certain political and ideological choices visible in literary texts underline national specificities. My intention, as a citizen of Niger, is to contribute to bringing Nigérien literature, and the Nigérien novel, in particular, into the limelight. In fact, this production is only just emerging, as the first novel dates back to 1959. This paper focuses on the fundamental problem of the relation between the novel produced in Niger and the Nigérien society, and by extension, the relation between Nigérien literature and the society from which it is emerging. Based on a thematic study, in the spirit of socio-criticism, an attempt will be made to place a selected corpus of eleven novels, published between 1977 and 1993, in their context of emergence. The geographical (spatial and climatic) milieu is omnipresent and dominant in these works; focus on a traditional socio-cultural milieu is recurrent and is still of current importance, while the modern socio-cultural milieu is determinant but not quite as dominant as rural space. These are some of the basic elements composing the backdrop of Nigérien novelistic creation. They suggest aspects of a collective identity. Nonetheless these are not, in themselves, sufficient grounds on which to identify a specific literary production. Key words: Niger, Nigérien literature, novel, Nigérien geography, Nigérien climate, collective identity.

Literature, like all art, is in part geographically and historically determined. Despite its imaginary nature, literature maintains close ties with its context of emergence. African literature is in part an illustration of determinisms of this type and owes a great deal to colonial trauma. Nevertheless, it also draws on autochthonous myths - both old and new - on the colonial heritage, and on new mentalities generated by decolonisation and other factors. However, certain political and ideological choices visible in literary texts underline national specificities.

In Niger, a recent and little known literature written in French has arisen from the shock of the colonisation of French West Africa whose first French colonial outposts date back to 1867. It was not until 1922 that the country became a colony of French West Africa. This situation explains the meagre volume of Niger's young literature as compared to 
that of other countries like Senegal (where the focus was placed on written literary production as early as the second half of the $19^{\text {th }}$ century), Benin and Congo.

In fact, there exists a written literature on Niger in French, written by French nationals, dating back to the end of the $19^{\text {th }}$ century. This literature includes novels, short stories, poems and plays in addition to documentary texts such as missionary reports and travelogues. Hence, Jules Verne's Cinq semaines en ballon (Five weeks in a balloon) appeared as early as 1863 in the category of adventure novels and in two of its the forty-four chapters the reader is given a glimpse of Niger: of Samergou, Zinder and Songhay country. In 1902, Henri de Noville published Le Trésor de Mérande (Mérande's treasure) in which a young man travels across parts of Africa including the Songhay country. In the novel category itself, there is Ma femme au Niger (My Nigérien wife) by Edouard de Meringo published in 1919 and depicting the community of colonizers in a fairly depressing atmosphere. La Grande Fauve (The great beast) by Christian Chéry, published in 1955, tells the story of a young man from the colonial community and of his passion for a young Nigérien woman, which ultimately drives him to commit murder.

In the category of short stories, Jean d'Esme published Sable de feu (Burning sand) in 1949, a collection of three stories including "La marche vers le soleil" ("Walk towards the sun") set in Niger. It recounts the murder of Cazemajou by Voulet and Chanoine in Zinder. As far as poetry is concerned Michel Péron published L'ère nigérienne (The Nigérien age) in 1926. Two poems on the Peul and Touareg in this collection are of particular interest to Niger. A number of poems, mostly for children, published by Andrée Claire in the newspaper Le Niger (Niger) between 1963 and 1974 are also worth a mention. Finally in theatre, François de Curel produced Le coup d'aile, (The flap of a wing), a play in three acts, in 1905, following the Voulet-Chanoine affair. ${ }^{1}$

The subject matter of this literature ranges from adventure to history and entails depictions of society and of power structures under colonisation, depictions of the Nigérien society of the period, mixed couples and similar topics. It was not until the eve of the Second World War that authors from Niger published their first works. On the eve of independence in 1959 the first Nigérien narrative in French, Les grandes eaux noires (The great dark waters) by Ibrahima Issa was published whereas Force Bonté (Strength and goodness) by Bakary Diallo in Senegal, L'esclave de Couchourou (The Slave of Couchourou) in Benin were published as early as 1926 and N'Gando, Le Crocodile (N'Gando, the crocodile) by Paul 
Lamomi-Tshibamba from the Congo in 1948. This new tradition of literary writing in French has a variety of relationships with the French literary tradition, ranging from imitation to refutation, from contestation to indifference, and this remains true regardless of the genre considered.

The purpose of this article is to establish whether or not the Nigérien novel provides an accurate account of Nigérien geographical, historical and sociological realities. In other words, in what ways and to what extent can the novel produced by Nigériens be perceived as a specific national cultural product. This study explores the fundamental problem of existing (often ambiguous) relations between the novel and society in general and between the literature produced in Niger and the Nigérien society in particular.

Firstly, this paper will look at the relationship between the Nigérien novel and its environment. It will consider the elements from this environment that contribute actively to the production of novels. Secondly, it will attempt to determine the specifically local characteristics of the Nigérien novel in the event that these exist in the first place. This study is based on a combination of the thematic and socio-historical perspectives.

For formalists, the creative literary process is organized along two important lines: the choice of the theme and its elaboration. Tomachevski suggests in his article "Thématique" (Themes) that the importance of a work depends essentially on the reader and on the topicality of the theme. Daily circumstances determine the basic form of topicality. He notes however that topical works do not outlive the temporary significances they stem from as themes arising from current affairs rapidly lose their importance to the extent that they are unable to keep up with the variability of public interest. Inversely, the more important and everlasting the theme, the greater the viability of the work concerned. Universal interests can be attained by stretching the limits of topicality. However, to be universal themes must draw on concrete subject matter as their interest depends on their contemporary relevance (Tomachevski, 1965: 226).

Thus, the timing of a literary work as well as its themes are determining factors with respect to the interest arresting potential of a given work. In addition, the literary tradition and the objectives it sets play an equally important role and must be included among these historical conditions. Textual sociology or social criticism also seeks to define the discursive relations between theory and ideology and between theory 
and fiction. The mission of textual sociology as advocated by Zima (1985: 16) is to "become at the same time an empirical and critical science, capable of taking into consideration textual structures and the social context from which they (the literary works) derive." ${ }^{2}$ In fact, according to Zima, the literary universe as an autonomous system should react to cultural, social and economic changes. However, he claims, it must be clear to what extent the semantic universe and the narrative of the novel constitute social facts. To what extent can the novel be linked to the socio-linguistic and discursive structures of a period? Moreover, all discourse, whether theoretical or literary, deforms the reality on the semantic and narrative level. This study proposes a reflection on these deformations based on a corpus of eleven novels published between 1977 and 1993: Waay dulluu (Ada Boureima, 1981), Abboki, ou l'appel de la côte (Abboki, or the call of the coast, 1978) and Caprices du destin (Destiny's whims - Halilou Sabbo Mohamadou, 1981), La camisole de paille (The camisole of straw - Adamou Idé, 1987), Souvenirs de la boucle du Niger (Memories of the bend in the River Niger - Kélétigui Amadou Mariko, 1980), Sarraounia (Abdoulaye Mamani, 1980), Gros plan (Close-up, 1976) and Le Représentant (The representative - Idé Oumarou, 1977), Quinze ans çà suffit! (Fifteen years are enough!, 1977), Le Nouveau Juge (The new judge, 1982) and L'Honneur perdu (Lost honour - Amadou Ousmane, 1993).

\section{Dominant factors in the production of the Nigérien novel}

In all the novels cited above, one notes the pre-eminence of (the socioclimactic and geographical) environment. In fact, these novels deal with the difficulties related to this environment in which peasant populations evolve and which pushes many to migrate in search of a better future. Environmental factors include poor soils, high temperatures, irregular and insufficient rainfall, desertification and frequent droughts. They result in a massive migration of the rural populations in the direction of the city and abroad. In Quinze ans çà suffit! the narrator expresses anxiety concerning inadequate rainfall: "while $400 \mathrm{~mm}$ is considered a normal rainfall, only $130 \mathrm{~mm}$ had fallen, that is to say three times less than usual" (Ousmane, 1985: 14). ${ }^{3}$

Environmental pressures of this kind are a constant theme and source of concern for the Nigérien novelist in particular, whose objective is to reconcile populations with a difficult environment. In Mohamadou Halilou's Abboki, ou l'appel de la côte the main character, Amadou ends up learning from his Ivorian adventure that "there is no need to leave 
one's country in order to become rich. The land of our ancestors is true wealth" (Halilou, 1978: 53). ${ }^{4}$

The novelist displays his intention of building awareness concerning the illusions of all those for whom the dream of happiness is conditioned by exile. He claims, citing a popular Nigérien proverb: "un lion devient un rat dans le village d'autrui" (a lion becomes a rat in other people's village).

The traditional (pre-colonial) socio-cultural environment is a recurrent and omnipresent social space in these novels as in real life. Certain practices suggest, moreover, an obsessive attachment to the past visible in the nurturing of oral traditions, for example. The voluntary rehabilitation of a denied past and of defiled black identity determines a nostalgic idealisation of the traditional world while motivating the memory work to which writers dedicate their efforts. Abdoulaye Mamani's novel Sarraounia is a case in point. It magnifies traditional moral values like dignity, courage, valour, tolerance and respect:

The battle will be fierce, but we will fight until the last, because it will never be said that the Aznas surrendered without a fight. Do not forget that in fighting to protect our families and our freedom we are also fighting for the honour of all Aznas, for the NAME of the Aznas! Yes! We will fight until our deaths so that, when our bones whiten in the sand, our griots, the sons of our griots and the grandsons of our griots will sing the praises of the Aznas' courage and honour.

I did not leave a son behind for the Aznas, but I will bequeath to them more than a son, more than life, more than all wealth, I will bequeath to them a NAME. I have given to the Azna people the pride of BEING (Mamani, 1980: 116). ${ }^{5}$

The modern (colonial and postcolonial) socio-cultural environment, though a determining factor, is not as dominant and does not carry the same weight as the landscape or physical milieu and the human and cultural rural environment. The former is progressively eclipsed by other burning issues. In fact, there is a shift of focus from recrimination against the White man and against colonisation to affirming a specific identity or négritude. Added to this identity quest, other important themes include the burning questions of current affairs at the time. One example is the subject of drought. An everlasting problem, this sometimes reaches the level of a major crisis in a country like Niger where agriculture remains the primary resource for at least $80 \%$ of the population. 
The subject matter of tradition, traditional practices and customs facing modernity is recurrent and topical. Characters like Fatou in $\mathrm{La}$ camisole de paille reveal the tension generated by social change seen variously as a desire for emancipation, a rejection of restrictive or inhibiting aspects of tradition, the obsessive recourse to certain religious practices (recourse to the services of Islamic religious authorities marabouts - or sorcerers). Protagonists or secondary characters often resort to animistic practices to get out of trouble, to obtain protection from enemies or to acquire certain esoteric powers.

In Caprices $d u$ destin the character Kasko, a candidate in a local government election (candidat à la deputation) seeks out the village animist priest (le féticheur du village), Boka, in order to increase his chances of success. Similarly, in Quinze ans çà suffit! Sidi Balima, a parliamentarian accused of misappropriating food aid for famine victims relies on the skills of his personal marabout, El Hadj Badara to escape sanctions. In Le Représentant Zéno, the wife of Siddo the boatman, calls on Tanti Binta's supernatural powers to save her husband from the goum (as the local populations called the goumiers or Touareg militia recruited by the government, and who were never seen without their rawhide whip), Touré, who is set on exploiting and destroying him. There are countless other examples of difficult situations of this type determining recourse to religion or magic.

Following Tomachevski's claim in his article "Thématique" I argue that the interest of a work depends on the topical relevance of the subject matter discussed. But more sustainable concerns are also important. Indeed, droughts, rural migration, and social stress leading to magic-religious practices like the recourse to marabouts (maraboutage and fetishism, for instance), are some of the tribulations of the Nigérien society that novelist explore. I also agree with Tomachevski that the themes of a literary work are not only factual but are "usually coloured by emotions" (habituellement coloré d'émotion), "evoke a feeling of indignation or sympathy" (éroque donc un sentiment d'indignation ou de sympathie) and "a value judgment" (évoquera toujours un jugement de valeur). The practices of the Nigérien novelist bear out this viewpoint, as will be noted shortly.

The Nigérien author is a bearer of messages. His goal is to denounce the society's failings and to try and find solutions to them. To this end, the works are didactic and moralizing, drawing on either historical or rural realities. Moreover, depending upon the chosen inspiration, several types of novels exist. The historical novel, for example, as its name 
indicates, stems from history (from a specific historical event). Historical truth, when established, undergoes a profound change in the creative process. The historical novel also borrows from the techniques and narratives of the traditional tale, but it is above all the product of the author's imagination, allowing him to transmit his own ideology as well as that of the community.

In Sarraounia, for example, the personality of the heroine, depicted as a mythical figure, is highlighted with rehabilitation in mind. Sarraounia becomes a symbol of the Azna people. The preservation of the moral and cultural values of this people is presented in a positive light, while the invaders, the white usurpers, are depicted negatively. Sarraounia is endowed with qualities befitting a goddess: courage, bravery, dignity, power, a sense of honour, a sense of tragedy, beauty, elegance, class and femininity (without the negative side effects of femininity - she never experiences the pangs of childbirth nor the wear and tear of repeated pregnancies that alter a woman's figure; like men, she enjoys great sexual freedom, unlike women of her time).

L'Honneur perdu also takes the history of Niger as its source of inspiration. It recounts the role played by the Nigérien people (workers' and teachers' unions and political parties) in the advent (l'instauration) of democracy with a special focus on the events of $9^{\text {th }}$ February 1990, when students and police faced each other, resulting in the loss of life. ${ }^{6}$

The autobiographical novel makes ample room for social reality, but accords scant importance to fiction. It takes the form of a chronicle or eyewitness account in which the narrator and the author seem to be one and the same. Such is the case of Mariko's Souvenirs de la boucle du Niger which evokes autobiographical events and experience of the region which at the time encompassed Mali, Niger and parts of Upper Volta (present day Burkina Faso) reunited under a single administration. Mariko was a veterinary surgeon under the colonial regime. In the same manner, Mahamadou Halilou's Caprices du destin relates various autobiographical events: first as a young country schoolteacher in confrontation with the colonial administrator; then as a fervent militant for the PPN/RDA; and finally as a dissident and active member of the Sawaba, a leftist party incarnating opposition to the first (dictatorial) post-independence regime. ${ }^{7}$

However, a second type of figure can also be found, in which either a main character (Gambo in Waay dulluu), or the author and a main character (Mahamadou Halilou and Amadou in Abboki, ou l'appel de la côte) act(s) as narrator(s). It must be noted though, that Halilou figures 
as a narrator only in the first chapter of the work before Amadou steps in to narrate the rest of the story. The choice of first person narrative, with its exclusive focus on the narrator's discourse, undermines the quality of the dialogue by making it dependent, to a great extent, on the point of view of only one of the inter actants.

The realist novel draws on everyday experience as a source of inspiration with a focus on either negative or positive elements. Reality, it can be said, thus occupies an important place in the production of the novel in Niger. Fiction is, for the author, merely a means of exposing a few truths or his vision of the truth. In fact, the Nigérien novelist paints a convincing picture of the characteristics of his environment and of his times. His work reveals a concern for the problems of people and of society with a particular emphasis on the aspirations of minorities and of poor, destitute and oppressed people (see Quinze ans çà suffit!, Le Nouveau Juge and Sarraounia).

The Nigérien author often employs caustic satire of the political powers in his denunciation of social injustice and abuse of all types. Apart from Sarraounia, set at the end of the $19^{\text {th }}$ century, novels produced in Niger tend to concentrate primarily on contemporary reality. They reflect certain characteristics of the Nigérien society, thus filling the criteria of the definition of social criticism expounded by Zima. Moreover, this perspective allows the reader to follow the developments and diverse changes experienced by this society in the course of history.

The Nigérien novel thus provides insights into the political evolution of the country. Concerning the colonial experience we note ( $\mathrm{Ca}$ prices $d u$ destin, Souvenirs de la boucle du Niger and Sarraounia): the unjust actions (exactions) committed by the colonizers to the detriment of the local populations for whom they feel nothing but contempt, as expressed by major Goumaibe. "Only bullying can teach niggers, these big children in whom we must inculcate by all means the blessings of our noble French civilization" (Halilou, 1981: 28-29). ${ }^{8}$ Other texts focus on the post-independence period (Abboki, ou l'appel de la côte, Quinze ans çà suffit! and Gros plan) during which the people, displeased with the indifference, lack of concern and selfishness of the new leaders loose hope in change. "People have always enumerated for us the blessings of Independence. Happy, we declared the end of the abuses, corruption, bullying and humiliations, since the colonizers left. Our brothers now hold the power. Unfortunately, as you notice, all is but vain illusions" (Halilou, 1978: 19). ${ }^{9}$ Finally, certain works explore the man- 
ner in which the Nigérien population welcomed the military coup under general Kountché in Quinze ans çà suffit! and the conduct of the leaders of the regime that resulted from this coup. In Le Représentant we read: "On streets the demonstrators, by their thousands, marched, shouting: 'Long live the Army! Down with the party! Fifteen years are enough!'” (Ousmane, 1985a: 134). ${ }^{10}$

In conclusion, it can be said that the Nigérien novelist makes a case for a kind of social development that takes global changes and new social realities into account while maintaining respect of the identity and values of the Nigérien people in order to produce a society freed from glaring social injustice, whose political leaders have the interests of the people at heart: "I would like to come to the rescue of all those bullied, oppressed, rejected by society and others like them, many of whom in this country, for many reasons, are pushed aside, downtrodden, forgotten, judged and too quickly condemned as if they were not human beings in their own right" (Ousmane, 1985a: 121-122). ${ }^{11}$

In the novel all these concerns are expressed through explorations of the spatial-climatic environment and the traditional and contemporary socio-cultural environment. So, can one speak of a specifically Nigérien novel, and by extension, of a Nigérien literature?

\section{The production of the novel: in search of an identity}

Since 1976 and the publication of Robert Cornevin's Littérature d'Afrique noire de langue française (African literature in French) and of Jean-Baptiste Tati Loutard's Anthologie de la littérature congolaise d'expression française (An anthology of Congolese Literature in French), there has been an increasing tendency to study African francophone literature from a national perspective. The Congolese novelist Emmanuel Dongala explains the reasons for this change:

If it is legitimate to speak of "African literature", then it becomes increasingly obvious that the countries made uniform long ago by colonization have more and more differentiated themselves from one another as the years go by, and everyone of these societies give rise to concerns or at least to different priorities depending upon the type of political regime they are subjected to (in Chevrier, 1984: 9). ${ }^{12}$

Consequently, Chevrier does not advocate viewing African literature as a monolith but recommends, instead, that national cultural characteristics be taken into account. Neither Cornevin nor Tati Loutard, however, clearly states the theoretical problem of national literature, a pro- 
blem that, in contrast, is treated without ambiguity by Arlette and Roger Chemain in Panorama critique de la littérature congolaise (An overview of Congolese literature, see Koné et al., 1979), in Anthologie de la littérature ivoirienne (An anthology of Ivorian literature, 1983) and by Kadimu Nzuji in the preface to the Anthologie de la poésie camerounaise d'expression française (An anthology of Cameroonian poetry in French), compiled under the title of Poèmes de demain (Poems for tomorrow, 1982) by Paul Dakeyo. In the same manner, it is not possible to speak of national literature without referring to the work by the Beninese critic, Adrien Huannou, Les littératures nationales (National literatures, 1989), which greatly expanded the topic.

For Kadimu Nzuji each country experiences specific problems, to which, depending on its interests and objectives, it tries to find specific answers. Consequently, he claims, literature which is itself a response to the challenges of its times and environment, naturally becomes infused with the ideological currents that inform and sustain its site of production. It establishes itself as a mirror of the collective conscience.

For Arlette and Roger Chemain three conditions are needed for a pertinent discussion of national literature: (a) a sufficient number of authors and a substantial body of published work, (b) a certain continuity (rooted in the past and vitality of this literature) and (c) the existence of characteristics common to the whole body of work deriving from common cultural traditions and a historical experience (Chevier, 1984: 230).

For Ngandu Nkashama the literary works themselves reveal the peculiarities of the situations specific to each country; while Huannou on the other hand gives precedence to geographical and cultural criteria that he reckons are sufficient to establish the conditions of a national literature. It is more important, Huannou adds, that there be a community of social and cultural preoccupations among authors from a country and that the relationship between the literature and the history of its country of origin be studied.

A national literature can be considered to exist once a certain volume of works has been produced, if these are specific in their subject matter, style and anchorage within a culture, and serve as sources of inspiration and reflection available to its readers. It is at this point that a careful study of the preoccupations specific to a certain author comes into play: his literary or cultural influences, the imagination that inspires his work, the spirit of a national or ethnic group to which he belongs and for which he can serve simultaneously as spokesperson and mirror. 
Based on the observations and notions on the national dimension of literature developed by these critics, I will attempt to determine whether the Nigérien novel exists. Do the texts produced in Niger display distinctive national traits? We need to bear in mind beforehand the fact that national borders do not preclude shared characteristic between neighbouring national literatures.

Identification of the country in which the action is set can be seen as one aspect of a national literature. However, despite concerns of collective identity the space in which the action is set sometimes is either anonymous or fictitious though certain semantic features of the text, the structure of the work (its style and themes) might constitute useful clues. Other markers include reference to certain social practices, historical events or collective representations.

Yet, place anonymity is usually a deliberate choice in cases like these. Authors who make this choice seem more intent on underlining the cultural importance of space and of the human experience it houses as opposed to the purely physical, geographical significance of a setting. Other novelists choose to situate the action of their novels in a readily identifiable socio-political setting the reader has no problem locating on a map of Africa. This choice suggests two main objectives: placing emphasis on a specific geographic site filled with cultural significance; presentation of the facts and experiences of situated people through the use of a new spatial-temporal category, namely the nation. But political constraints also come into play. Authors focalizing on political issues, questioning the meaning of independence and denouncing an intolerable socio-political injustice often choose to set their works in imaginary countries.

In this case texts do not provide clear clues (message clair) based on which the reader might identify the fictitious setting. At another level, this anonymous setting seems to refer to "Africa in general" or "to developing countries".

We are left to wonder whether or not this strategy of concealment represents a precautionary measure aimed at escaping from the vengeance of the powers in place or if it is a way of signifying that, beyond the borders of micro-states, specific socio-political dilemmas are also general problems deriving from neo-colonialism, affecting various countries and revealing profound traces of anxiety and rupture.

National history, according to Ibrahima Baba Kaké, must be an artistic expression and lesson of morality. Historically inspired work retains multiple ties to history. It takes history as its subject, but is itself 
subject to history. It is an integral part of history, which "conditions (...) as to its sudden appearance, forms, evolution, social impact" (Lukács, 1965: 2). ${ }^{13}$ The author of a historical work is himself conditioned by the historical society in which he lives; which informs and accounts for his vision of the period he has chosen for his novel; as well as this choice itself. In addition, the objectives of a work of such magnitude is to reflect on the past of the chosen locality, rehabilitate heroes of the past, to use this past to explore present problems (including that of identity) and finally to draw lessons from it. This is what Baba Kaké calls the re-conquest of historical time and the space of the nation.

As such, a national literature must convince people that it has a specific identity. However, the current search for the expression of a national literary dimension also involves demanding a presence in the world. Writers are no longer contented to limit the scope of the reception of their work to a local audience composed of compatriots or people of their own race. They are keen on communicating with people everywhere. Hence continental and national dimensions intersect and complement each other.

The application of this analysis to the novel in Niger shows that it satisfies only some of the criteria for defining national literature mentioned above. Nigérien novels bear the imprints of the local environment (spatial-climatic, socio-political, traditional and contemporary cultural conditions). The Nigérien novelist uses his writing to represent the realities of his country. Moreover, there are facts, psychological responses (ways of perceiving and conceiving), sociological and cultural aspects that surface in "the writing of the country".

Toponyms, anthroponyms, expressions and literal translations, popular wisdom convey the subtlety of Nigérien languages (my reference here concerns Zarma and Hausa). Let's take an example. In French "my mouth is full of tobacco" is a literal translation of the Hausa expression "baki na da taba". Only a native speaker or a person with a good grasp of Hausa fully understands what it means, that is: I have no intention of expressing my opinion on this subject, if you don't mind.

To return to specific characteristics of the novel produced in Niger: it can be asserted that there are indeed common social and cultural preoccupations among Nigérien authors: yearning and fighting for a fairer society that respects people's cultural values and identities; freedom from all forms of abuse, a break with negative traditions.

An overview of the themes and thematic structures dealt with in the novels that form the corpus of this study reveals a subject matter that is 
not specific to the literature of only Niger. On the contrary, it tends to be regional (Sahelian) or universal.

Colonisation and successive corrupt, catastrophic post-colonial political administrations, drought, forbidden love, generational conflict, and depictions of traditional society constitute, among others, the elements of this subject matter. Many African authors have covered these different themes. The Senegalese writer and filmmaker, Sembène Ousmane (Les Bouts de bois de Dieu, [God's bits of wood, 1960]) denounces the abuses of a colonial administration, a theme that is also found in novels of the Cameroonian writers, Mongo Béti (Ville cruelle, [Cruel city, 1954]) and Ferdinand Oyono (Le Vieux Nègre et la médaille, [The Old Negro and the medal, 1956], Une Vie de boy, [Houseboy, 1956]). The Guinean writers, Alioum Fantouré (Le Cercle des tropiques, [Tropical circle, 1972]), Tierno Monénembo (Les Crapauds brousse, 1979 [The Toads' jungle]) and William Sassine (Le jeune homme de sable, [The young man of sand, 1979] and the Ivorian Ahmadou Kourouma (Les Soleils des indépendances, [ The Suns of Independence, 1970]) all put postcolonial regimes and their new leaders on trial. The Malian writer Mandé-Alpha Diarra (Sahel, sanglante sécheresse, [Sahel, bloody drought, 1981]) exposes the ravages of the drought and of the abuse of political power. Camara Laye (L'Enfant noir, [The black child, 1953]) from Guinea depicts traditional African society.

If the themes developed in this literature can be considered universal, its expression (the style in which it is expressed) is less so. It does not matter that it uses the language of the former colonizer; its expression bears the imprint of the Nigérien society and its preoccupations. The images, symbols, beliefs, myths and legends of Niger heavily influence the style of the authors.

The question of the retrieval (de la reconquête) of historical time seems to be a growing concern among Nigérien novelists. They tend to anchor their texts in their homeland, to relive the historical past and consequently to portray the heroes who influenced the history of this area. In this, André Salifou and Mamani Abdoulaye are the leading figures.

This measure (admitted or not) aims at asserting an identity beset by colonial and neo-colonial pressures. The postcolonial state, perceived as a "product of the will of an entire people", very quickly appeared to be a monster devouring its children. Its characteristics include an intrusive bureaucracy, hyper-centralization assorted with under-administration at local level (sous-administration à l'échelon local), that is little or no representation of the central state in rural areas excepting the village chief, remnants of tribalism, a resurgence of favouritism, nepo- 
tism, and a single party acting as the buttress of national identity. Mention must also be made of the army that increasingly asserted itself as the sole principle and the unique form of government.

Most of the novels that are discussed in this study clearly suggest this framework. Such is the case of Abokki, ou l'appel de la côte that opens with the following prelude: "In Niger the rural migration and particularly the migration to countries on the coast are permanent realities that can neither be neglected nor ignored." ${ }^{14}$ The sites serving as settings for the action are well defined: Niger and then the coastal countries (in this instance the story refers to Côte d'Ivoire). The presence of city names (Bouza, Tahoua), villages (Garadoumé) or regions (the Magia valley), all easily recognizable and identifiable on a map of Niger, denotes Mahamadou Halilou Sabbo's desire to "territorialize" his work. This is also the case in Gros plan where Idé Oumarou takes Niamey as the setting for his story: "Capital of Niger, Niamey is nonetheless, in many regards, a small village" (Oumarou, 1987a: 50). ${ }^{15}$ In the case also, there is no doubt that the author wishes to anchor his novel in his own country.

For those unfamiliar with the country, Mahamadou Halilou Sabbo's and Idé Oumarou's identification of sites are welcome. However, for natives or those in the know various clues allow recognition. These include toponymic hints: the towns of Tillabéry and Filingué, the Big Market (transportation to Zarma, "Habu Béné" which means "upper market"), institutions, private or state companies (BONAF, Crédit du Niger, CNCA, USN, PPN-RDA and Cours Normal de Tillabéry). ${ }^{16}$

For those novels that do not clearly identify the setting reference contained in toponyms, anthropnyms, living conditions and the sociopolitical situation make identification possible. Amadou Ousmane in his three works Quinze ans çà suffit!, Le Nouveau Juge and L'Honneur perdu describes imaginary countries that are thinly disguised; through conscious or unconscious actions by the author, they bear the imprint of their identity. Through the [fictional] republics of Bentota, Babakassa or Bamoul, the informed reader easily identifies Niger.

The famous drought described in Quinze ans çà suffit! reminds Nigériens of the drought that caused great damage to Niger and the Sahel in 1974. In addition, the case of misappropriation of provision from international aid groups is an exact replica of the scandal of the OPVN ${ }^{16}$ that broke out in Niamey at this same period. This striking double coincidence becomes clear when Amadou Ousmane, while maintaining that the story is fictional, claims that he drew from his 
observations as a journalist on the matter (he even reported on the issue). This is also the case of an anecdote in Le Nouveau Juge where the son of a dignitary of the party in power kills one of his friends in a brawl during a dance. A similar event happened in Niamey and there are parallels between the two stories (the protagonists, the motive, and the crime).

L'Honneur perdu, for those in the know, merely retraces the events that led Niger to the adoption of a multiparty system. The actions taken by Nigérien scholars and students, labour unions, opposition to officers and non-commissioned officers who for several years held the reins in the country in hand, the death of three students during the $9^{\text {th }}$ February 1990 march, the "national" funerals they obtained indicate the nature of Niger's political life on the eve of this era of democratisation. In addition, it is impossible not to recognize the former president of Niger, the General Ali Saibou in the character of Général Okala. Everything, from the representation of him as a good-natured man, without malice, to the new five year mandate he had just won and to the announcement he made to recall the army from all the top political positions in the country, confirm this view.

All of the above examples show that the novel produced in Niger owes a great deal first to the landscape (the physical space), second to the country (a landscape infused with human presence and cultural meaning). The question of identity or of the recapturing of the past is a preoccupation of the novel produced in Niger. Sarraounia by Abdoulaye Mamani surely represents the most amazing attempt to explore the question of Nigérien identity. This will to rediscover the roots of Nigérien identity in a female figure and in animism on top of that represents a deliberate effort on the part of Mamani to remind his compatriots that Niger has at its disposal values pre-dating those introduced by Islam and colonisation. Indeed, the will shown by Nigérien novelists to rehabilitate the Nigérien past and all the formal attempts made to this end (depiction of traditional society, reinstitution of the oral tradition) cannot be ignored.

However, the use of the colonial language, French remains one of the problems facing literary production in Niger, as many Nigériens do not understand it. Only 30\% of the population can read and write French. This considerably limits the reading public, creating a divide between Nigérien writers and the strata of society (the peasant population) they most fervently defend. Yet this writing is not ineffectual since it keeps leaders in line (by denouncing and criticizing their actions), 
calls on international opinion to bear witness, educates, entertains and moralizes.

Despite various difficulties, the novel has emerged in Niger, beginning with Ibrahima Issa's Les grandes eaux noires (The great black waters, 1959) and continuing, ten years later, with Boubou Hama's Kotia Nima (1969). The evolution of the novel parallels the difficulties of the entire Nigérien literary production, with promising periods (1960-1974), periods of guarded silence (1974-1987), and even total silence in certain genres.

From 1960 to 1974, among writers such as Djibo Mayaki, André Salifou, Abdoulaye Mamani, Abdoua Kanta, Boubou Idrissa Maïga and Bania Say, Boubou Hama stands out because of his prolific production, many of them historical or ethnographic works. His literary - and philosophical - production includes: essays, Cet autre de l'homme (The other man inside me, 1972), Le double d'hier rencontre demain (Yesterday's spirit meets tomorrow, 1973), Aujourd'hui n'épuise pas demain (Today does not outrun tomorrow, 1973); novels, Kotia Nima (Listen child, 1969), L'extraordinaire aventure de Bikado, fils de noir (The extraordinary adventure of Bikado, a black boy, 1971); of plays, Soni Ali Ber (1971), La force du lait (The power of milk, 1973); of tales, Contes et légendes du Niger (Short stories and legends of Niger, 1971) in seven volumes and Izé-Gani (1985).

The period between 1974 and 1987 coincides with political response via literature to the military regime (régime d'exception), and was the most productive period as far as the novel is concerned.

During this period Nigérien novelists put the first post-colonial regime on trial in works such as Gros plan (1976) by Idé Oumarou, Quinze ans çà suffit! (1977) by Amadou Ousmane; of colonization, Sarraounia (1980) by Mamani Abdoulaye, Caprices du destin (1981) by Mohamadou Halilou; or they put Nigérien society itself on trial in Le Nouveau Juge (1982) by Amadou Ousmane, Le Représentant (1977) by Idé Oumarou and La camisole de paille (1987) by Adamou Idé.

The period between 1987 and 1990 was a time of improved sociopolitical relations preceding the multiparty era. Novelists were completely silent. A new generation of writers nonetheless sprang up thanks to the literary competitions organized by the $\mathrm{CCFN}^{16}$ and the Mois du livre (The Month of Books). These new writers, among them Alfred Dogbé, Mahamadou Moussa, Kangaï Seyni Maïga and Hélène Kaziendé would achieve recognition in two genres: the short story and poetry.

Since 1990, Nigérien prose has regained a degree of popularity thanks to the publication of new works: L'Honneur perdu (Lost honour, 1990), 
Chant du terroir (Song of the land, 1992), Fleurs confisquées (They took away the flowers, 1992), Saison d'amour et de colère (Season of love and anger, 1998), Les cauris veulent ta mort (The cowries want your death, 1999), Le témoin gênant (The disturbing witness, 2003). In addition, an important fact that cannot be ignored is that women are more and more interested in literature. No major work, written by a woman appeared between 1960 and 1987. Other than the collection of poetry, Alternances pour le sultan (Alternations for the Sultan, 1982) by Shaïda Zarumey, only a few isolated writings published in newspapers can be attributed to women. But a new generation of writers, that counts among them more and more women, has reversed this tendency. Educated and active women are winners of literary competitions (short stories and poetry competitions) and are rewarded with wider publicity.

Grounds for the emergence of new literary developments, rooted in the culture of the country, has been broken, even if the subject matter developed is not uniquely Nigérien (but also concerns the Sahel region, Africa, the world). Yet the imaginary these works explore expresses the beliefs, myths and legends of the country in a particular way. Western influence (present in works such as Les grandes eaux noires by Ibrahima Issa) seems to be on the decline.

\section{Conclusion}

Thus, the novel produced in Niger bears the imprint of its environment. The geographical or spatial-climatic milieu is clearly present and predominant, the traditional socio-cultural environment recurrent and the topical, contemporary socio-cultural environment determinant but not dominant. This genre is, as we have seen, an important aspect of the emergence of literary writing in Niger. However, a definitive typology of the Nigérien novel seems premature despite evidence of certain specificities. An in-depth study, enlarged to include the production of Niger's neighbours like Burkina Faso and Mali, would be needed to clarify this question. It would help us to decide whether the emphasis is to be placed on regional or on national criteria. A good guess is that both perspectives are important and complementary, but further research is needed to provide the specific details of a regional as well as local typology.

Translated by Fara Rabenarivo.

Le texte original en français est disponible sur www.letterkunde.up.ac.za 


\section{Notes}

1. During 1898-1899 a column of French soldiers, aided by numerous African foot soldiers, cavalry, burden-bearers and servants, forcefully recruited or voluntary mercenaries, not to mention abducted women, under the leadership of Paul Voulet and Julien Chanoine, committed acts of wanton violence killing several thousand inhabitants of villages in Niger and Chad [eds.].

2. "devenir une science à la fois empirique et critique, capable de tenir compte des structures textuelles et du contexte social dont elles (les œuvres littéraires) sont issues" (Zima, 1985: 16).

3. “alors que $400 \mathrm{~mm}$ de pluie sont considérés comme une pluviométrie normale, il n'était tombé que 130 mm, c'est-à-dire trois fois moins que d'ordinaire" (Ousmane, 1985: 14).

4. “il n'est point besoin de s'expatrier pour s'enrichir. La véritable richesse, c'est la terre de nos ancêtres" (Halilou, 1978: 53).

5. "La lutte sera dure, mais nous nous battrons jusqu'au dernier, car on ne dira jamais que les Aznas se sont rendus sans combat. N'oubliez pas qu'en luttant pour défendre nos foyers et notre liberté, nous nous battons aussi pour l'honneur de tous les Aznas, pour le NOM des Aznas! Oui! Nous nous battrons jusqu'à la mort pour que, quand nos os auront blanchi dans le sable, nos griots, les fils de nos griots, les petits-fils de nos griots chantent le courage et l'honneur des Aznas. Je n'ai pas donné de fils aux Aznas, mais je leur léguerai plus qu'un fils, plus que la vie, plus que toutes les richesses, je leur léguerai un NOM. J'ai donné au peuple Azna la fierté d' ETRE" (Mamani, 1980: 116).

6. The unions involved were the USTN and the USN (see also note 16) [eds.].

7. PPN/RDN (Parti Progressiste Nigérien pour le Rassemblement Démocratique Africain = Niger Progressive Party for the Democratic Union of Africans). At independence on $3^{\text {rd }}$ August 1960 the Niger Progressive party was the predominant political organisation, a branch of the Rassemblement Démocratique Africain (RDN), an umbrella body operating in several French West African territories. Sawaba, a leftist party, under the leadership of Bakary Djibo unsuccessfully campaigned for independence in the mid-1950s. For a discussion of this party's rebellion in the 1960s see van Walvaren (2003) [eds.].

8. "Seule la trique compte avec les nègres, ces grands enfants auxquels nous devons inculquer par tous les moyens les bienfaits de la noble civilisation française" (Halilou, 1981: 28-29).

9. “On nous a toujours vanté les bienfaits de l'indépendance. Heureux, nous disions finis les abus, la corruption, les brimades et les humiliations, puisque le colonisateur était parti. Nos frères détiennent à présent le pouvoir. Malheureusement, comme vous le constatez, tout n'est que vaines illusions" (Halilou, 1978: 19).

10. “Dans les rues, les manifestants, par milliers, défilaient aux cris de: vive l'Armée! A bas le parti! Quinze ans çà suffit!" (Ousmane, 1985a: 134).

11. "Je voudrais voler au secours de tous les brimés, les opprimés, les laisser-pour-compte et tous ceuxlà, nombreux qui dans ce pays, pour des tas de raisons, sont bousculés, piétinés, oubliés, jugés et condamnés trop hâtivement comme s'ils n'étaient pas eux-aussi des homes" (Ousmane, 1985a: 121122).

12. "S'il est légitime de parler d'une 'littérature africaine', il est de plus en plus évident que les pays autrefois uniformisés par la colonisation se sont de plus en plus différenciés avec les années qui passent, et chacune de leurs sociétés engendre des préoccupations ou du moins des priorités divergentes selon le type de régime politique qu'elles subissent...!" (Emmanuel Dongala cited in Chevrier, 1984: 9).

13. "conditionne (...) quant à son surgissement, ses formes, son évolution, son impact social" (Lukács, 1965: 2).

14. "Au Niger, l'exode rural et surtout l'exode vers les pays côtiers constituent une réalité permanente qu'on ne peut négliger ou ignorer" (Halilou, 1978: 5).

15. “Capitale du Niger, Niamey n'en est pas moins, à certains égards, un petit village" (Oumarou, 1987a: 50).

16. BONAF (Bonne Affaire Nigérienne = Good Nigérien Bargains); Cours Normal de Tillabéry = Teacher's Training College of Tillabéry; Crédit du Niger = Bank of Niger; CCFN (Centre Culturel Franco-Nigérien = Franco-Nigérien Cultural Centre); CNCA (Caisse Nationale de Crédit Agricole = National Agricultural Bank); OPVN (Office des Produits Vivriers du Niger = National Office of Agricultural Production), PPN-RDA (Parti Progressiste Nigérien pour le Rassemblement Démocratique Africain = Progressive Nigérien Party for Pan-African Democracy), USN (Union 
des Scolaires Nigériens $=$ Union of Nigérien Students) and USTN (Union des Syndicats des Travailleurs du Niger [Union of the Syndicated Workers of Niger]).

\section{Bibliography}

Baba Kaké, I. 1982. Combats pour L'histoire Africaine. Paris: Présence Africaine.

Boureima, A. 1981. Waay Dulluu. Niamey: Imprimerie Nationale Du Niger.

Chevrier, J. 1989. Littérature Nègre. Paris: Armand Colin-Nouvelles Editions Africaines.

Dakeyo, P. 1982. Poèmes de demain: Anthologie de la poésie Camerounaise d'expression Française. Paris: Silex.

Halilou, Sabbo, M. 1978. Abboki ou l'appel de la côte. Dakar: Les Nouvelles Editions Africaines.

- 1981. Caprices du destin. Niamey: Imprimerie Nationale Du Niger.

Huannou, A. 1989. Les littératures nationales. Abidjan: Ceda.

Idé, A. 1987. La camisole de paille. Niamey: Imprimerie Nationale Du Niger.

Koné, A. 1985. Du récit oral au Roman. Abidjan: Ceda.

Lukács, G. 1965. Le roman historique. Paris: Payot.

Mamani, A. 1980. Sarraounia. Paris: L'Harmattan, Collection Franco Poche.

Mariko, K.A. 1980. Souvenirs de le boucle du Niger. Dakar: Les Nouvelles Editions Africaines.

Midiohouan, G.O. 1977. L'idéologie dans la littérature Négro-Africaine d'expression Française. Paris: L'Harmattan.

Oumarou, I. 1987a [1977]. Gros plan. Dakar-Abidjan: Les Nouvelles Editions Africaines. 1987b [1977]. Le Représentant. Abidjan: Les Nouvelles Editions Africaines.

Ousmane, A. 1985a. [1977]. Quinze ans çà suffit! Dakar: Les Nouvelles Editions Africaines. 1985b. [1982]. Le Nouveau Juge. Dakar: Les Nouvelles Editions Africaines. 1993. L'Honneur perdu. Niamey: Nouvelle Imprimerie Du Niger.

Pageard, R. 1997. Mutations des mythes traditionnels Africains dans la littérature moderne. Limoges: Publications De Trames, Université De Limoges.

Revue 1991. Notre Librairie 107, Octobre-Décembre.

Salifou, A. 1973. Tanimoune. Paris: Présence Africaine.

1989. Histoire du Niger. Paris: PUF.

Sanon, B. 1983. Images socio-politiques dans le roman Négro-Africain. Sherbrooke: Naaman.

Tomachevski, B. 1965. Théorie de la littérature: Textes des formalistes russes. Paris: Editions du Seuil.

Tzvetan, T. 1965. Théorie de la littérature: Textes des formalistes Russes. Paris: Editions du Seuil.

Van Walvaren Klaas. 2003. Sawaba's rebellion in Niger (1964-1965): Narrative and meaning. In Jon Abbink, Mirjam de Bruijn \& Klaas van Walraven (eds.). Rethinking Resistance. Revolt and Violence in African History. Leiden, Boston: Brill, 218-252.

Zeraffa, M. 1871. Roman et société. Paris: PUF.

Zima, P.V. 1985. Manuel de sociocritique. Paris: Picard. 